\title{
The Importance of Ischemia Modified Albumin in Chronic Hepatitis $B$ and $C$
}

\section{Kronik Hepatit B ve C'de Iskemi Modifiye Albüminin Önemi}

\author{
(1) Arzu Şenol1', @ Semra Türkoğlu² \\ ${ }^{1}$ Fethi Sekin City Hospital, Clinic of Infectious Diseases and Clinical Microbiology, Elazığ, Turkey \\ 2 University of Health Sciences Turkey, Firat University Faculty of Medicine, Department of Nutrition and Dietetics, Elazığ, Turkey
}

\begin{abstract}
Objectives: In this study, it was aimed to investigate the ischemia modified albumin (IMA) and the IMA/albumin ratio (IMAR) and the relationship between these two parameters with fibrosis in patients with chronic hepatitis $B(\mathrm{CHB})$, hepatitis $\mathrm{B}$ e antigen negative chronic infection ( $\mathrm{HBI})$ and chronic hepatitis $\mathrm{C}(\mathrm{CHC})$.

Materials and Methods: This prospective study included 80 patients with $\mathrm{CHB}, 50$ patients with $\mathrm{HBI}, 30$ patients with $\mathrm{CHC}$ and 60 control groups. IMA level was measured using rapid colorimetric analysis developed (albumin-cobalt binding test). IMAR was calculated.

Results: Forty-two of the CHB cases were female and 38 were male (age range: $46.62 \pm 2.69$ ). Thirty of the $\mathrm{HBI}$ patients were female and 20 were male (age range: $40.83 \pm 3.71$ ). Ten of the cases with $\mathrm{CHC}$ were female, and 20 were male (age range: $41.35 \pm 3.58$ ). Thirty-three of the control group were female and 27 were male (age range: $30.45 \pm 1.08$ ). Serum IMA levels and IMAR, $\mathrm{CHB}, \mathrm{HBI}$, and $\mathrm{CHC}$ cases were statistically significantly higher than the control group $(p<0.05)$. However, in terms of IMA, IMAR, no statistically significant difference was found in the between $\mathrm{CHB}, \mathrm{HBI}$ and $\mathrm{CHC}$ cases. In $\mathrm{CHB}$ and $\mathrm{CHC}$, IMA and IMAR were statistically significantly higher in those with significant fibrosis than those with mild fibrosis $(p<0.05)$.

Conclusion: IMA and IMAR can be used as a marker in determining prognosis as an indicator of oxidative liver damage and in the evaluation of fibrosis (especially early detection of fibrosis).

Keywords: Chronic hepatitis B, HBeAg negative chronic infection; chronic hepatitis $\mathrm{C}$, ischemia modified albumin, ischemia modified albumin/albumin ratio
\end{abstract}

\section{ÖZ}

Amaç: Bu çalışmada, kronik hepatit $\mathrm{B}(\mathrm{KHB}), \mathrm{HBe}$ Ag negatif kronik enfeksiyon (HBI) ve kronik hepatit $\mathrm{C}(\mathrm{KHC})$ olgularında, iskemi modifiye albümin (IMA) ve IMA/albümin oranının (IMAR) tanı ve prognoz tayinindeki önemini ve bu iki parametrenin fibrozis ile olan iliş̧isini araştırmak amaçlandı.

Gereç ve Yöntemler: Prospektif olan bu çalışmaya KHB'li toplam 80 , HBI'li 50, KHC'li 30 olgu ile 60 kontrol grubu alındı IMA seviyesi, hızı kolorimetrik analiz (albumin-cobalt binding test) kullanılarak ölçüldü. IMAR hesaplandı.

Bulgular: KHB'li olguların 42'si kadın 38'i erkek (yaş aralığı: 46,62 $\pm 2,69$ ), HBl'li olguların 30'u kadın, 20'si erkek (yaş aralığı: $40,83 \pm 3,71$ ), KHC'li olguların 10'u kadın, 20'si erkek (yaş aralığı: $41,35 \pm 3,58$ ), kontrol grubunun 33 'ü kadın 27'si erkek (yaş aralığı: $30,45 \pm 1,08$ ) idi. Serum IMA düzeyleri ve IMAR, KHB, HBI, KHC olgularında, kontrol grubundan istatistiksel olarak anlamlı yüksekti $(p<0,05)$. Ancak, IMA, IMAR açısından, $K H B, H B \mid$ ve $K H C$ olguları arasında istatistiksel olarak anlamlı bir farklılı saptanmadı ( $p>0,05)$. $\mathrm{KHB}$ ve KHC'de, IMA ve IMAR, belirgin fibrozisi olanlarda hafif fibrozisi olanlardan istatistiksel olarak anlamlı yüksekti $(p<0,05)$.

Sonuç: IMA ve IMAR, oksidatif karaciğer hasarının bir göstergesi olarak prognozun belirlenmesinde ve fibrozisin değerlendirilmesinde (özellikle; fibrozisin erken saptanmasında) bir belirteç olarak kullanılabilir.

Anahtar Kelimeler: Kronik hepatit B, HBeAg negatif kronik enfeksiyon, kronik hepatit $C_{\text {, }}$ iskemi modifiye albümin, iskemi modifiye albümin/albümin oranı

Şenol A, Türkoğlu S. The Importance of Ischemia Modified Albumin in Chronic Hepatitis B and C. Viral Hepat J. 2021;27:53-56.

Address for Correspondence: Arzu Şenol MD, Fethi Sekin City Hospital, Clinic of Infectious Diseases and Clinical Microbiology, Elazığ, Turkey Phone: +90 5052975916 E-mail: asenol2017@gmail.com ORCID ID: orcid.org/0000-0002-8537-0195 Received: 13.02.2021 Accepted: 20.06.2021

${ }^{\circ}$ Copyright 2021 by Viral Hepatitis Society / Viral Hepatitis Journal published by Galenos Publishing House. 


\section{Introduction}

Chronic liver disease (CLD) is a liver pathology characterized by the gradual destruction of liver tissue over time; hepatitis B virus $(\mathrm{HBV})$ and hepatitis $\mathrm{C}$ virus $(\mathrm{HCV})$ viruses are the most common causes of CLD's morbidity and mortality worldwide (1). In hepatitis $\mathrm{B}$ e antigen ( $\mathrm{HBeAg}$ ) negative chronic infection $(\mathrm{HBI})$, despite the risk of developing cirrhosis (LC) and hepatocellular carcinoma $(\mathrm{HCC})$, these complications may not develop throughout their lives (2). Although albumin has many features such as antioxidant activity, and regulation of inflammatory response, it can affect the course of the disease and treatment results quantitatively and qualitatively, and is considered an important and negative prognostic factor (3).

The amino terminal end of the albumin molecule is the primary site for binding metal ions, cobalt and nickel, and under various conditions such as ischemia and oxidative stress (OS), the capacity of albumin to bind metals is reduced. This modified form of albumin, which is formed due to conformational change, is called ischemia modified albumin (IMA). Although IMA is a proven biomarker to increase in various OS-related diseases, the exact mechanism that leads to the formation of IMA is unknown. IMA is shown as a marker of ischemia and OS that occurs as a result of tissue hypoxia (4). In addition, it has been claimed that serum IMA level is associated with disease severity and may have prognostic use in chronic liver failure (5). Evaluation of the degree of necroinflammation and fibrosis in the liver is very important in the treatment decisions and follow-up of the patients (6).

In this study, it was aimed to investigate the importance of IMA and IMA/albumin ratio (IMAR) in diagnosis and determination of prognosis in chronic hepatitis $\mathrm{B}(\mathrm{CHB}), \mathrm{HBI}$ and chronic hepatitis $\mathrm{C}(\mathrm{CHC})$ cases and the relationship of these two parameters with fibrosis.

\section{Materials and Methods}

\section{Patient Groups}

This study is of 80 cases with $\mathrm{CHB}, 50$ cases with $\mathrm{HBI}, 30$ cases with $\mathrm{CHC}$ and 60 control group negative for hepatitis $\mathrm{B}$ surface antigen, anti-HCV and anti-human immunodeficiency virus, without a history of acute and chronic hepatitis and any chronic disease. Patients under 18 years of age, those with LC and HCC, those with chronic diseases (such as diabetes mellitus, coronary artery disease) were excluded from the study. $\mathrm{CHB}$ and $\mathrm{CHC}$ cases were divided into two groups as marked fibrosis (stage 3-4) and mild fibrosis (stage 1-2) (there were no stage 5,6)

\section{Determination of Serum IMA Level and IMAR}

Approximately $5 \mathrm{cc}$ of blood was taken from the peripheral venous blood from the patients and separated into their serum by centrifugation. Serums were stored at $-80^{\circ} \mathrm{C}$ in a deep freezer. Serums were brought to room temperature and thawed on the working day. IMA level was measured using a rapid calorimetric analysis based on unbound Co measurement, developed by Bar-Or et al. (7), after incubation with the patient's serum. This test measures the cobalt binding capacity of albumin in the sample. The absorbances of the test mixtures were measured spectrophotometrically at $470 \mathrm{~nm}$ by the albumin-cobalt binding test and the calorimetric method. Results were obtained in about
30 minutes and are reported as absorbance units. In addition, the IMA/IMAR was calculated using the following formula: IMAR=IMA/ serum albumin concentration $(\mathrm{g} / \mathrm{dL})$.

Biochemical tests of aspartate aminotransferase (AST), alanine aminotransferase (ALT) and albumin were routine analyzes performed in the laboratory with automatic analyzers. Liver biopsy specimens of $\mathrm{CHB}$ and $\mathrm{CHC}$ cases were scored using the Ishak histological scoring system (fibrosis was evaluated over 6). The study protocol followed the ethical guidelines of the 1975 Helsinki Declaration. Ethics committee approval was obtained from Firat University Institutional Evaluation Committee (approval number: 24, date: 31.05.2018) and informed consent form was signed by the patients.

\section{Statistical Analysis}

Data analysis procedures were carried out using SPSS 22.0 (Chicago, USA) package statistics software. Kolmogorov-Smirnow and Shapiro-Wilk normality analysis was performed to determine the conformity of continuous variables to normal distribution. Student's t-test was used for the analysis of continuous variables conforming to the normal distribution, and the Kruskal-Wallis test was used for the analysis of variables that did not comply with the normal distribution. Pearson's chi-square test was used for comparisons between the two groups. Numerical data were expressed as mean \pm standard deviation, and categorical data as \%. One-Way ANOVA test was used in multiple comparisons. $\mathrm{P}<0.05$ value was considered significant in statistical comparisons.

\section{Results}

Forty-two of the CHB cases were female and 38 were male (age range: $46.62 \pm 2.69$ ). Thirty of the $\mathrm{HBI}$ patients were female and 20 were male (age range: $40.83 \pm 3.71$ ). Ten of the cases with $\mathrm{CHC}$ were female, and 20 were male (age range: 41.35 \pm 3.58 ). Thirty-three of the control group were female and 27 were male (age range: $30.45 \pm 1.08$ ). Serum ALT levels in $\mathrm{CHB}$ and $\mathrm{CHC}$ were statistically significantly higher than $\mathrm{HBI}$ and control groups $(p=0.016)$. The demographic characteristics of $\mathrm{CHB}, \mathrm{HBI}$ and $\mathrm{CHC}$ cases and the control group, the mean and p-values of the laboratory tests are summarized in Table 1.

No statistically significant difference was observed the patients with $\mathrm{CHB}, \mathrm{HBI}$, and $\mathrm{CHC}$ between serum IMA level and IMAR, and age ( $p=0.515, p=0.249$, respectively) and gender $(p=214, p=0.273$, respectively). Also, there was no significant difference between IMA and IMAR and AST $(p=0.858, p=0.143$, respectively), ALT ( $p=0.539, p=0.326$, respectively), AFP $(p=0.289$, $p=0.304$, respectively). Serum albumin levels were statistically significantly lower in $\mathrm{CHB}(3.81 \pm 0.04 \mathrm{~g} / \mathrm{dL}), \mathrm{CHC}(3.75 \pm 0.03 \mathrm{~g} / \mathrm{dL})$ and $\mathrm{HBI}(4.03 \pm 0.03 \mathrm{~g} / \mathrm{dL})$ than the control group $(4.69 \pm 0.04 \mathrm{~g} / \mathrm{dL})$ $(p=0.001)$. Serum IMA levels and IMAR, CHB, HBI, and $\mathrm{CHC}$ were statistically significantly higher than the control group $(p=0.004$ for IMA, $p=0.001$ for IMAR, respectively). However, in terms of IMA level and IMAR, no statistically significant difference was found in the comparison between $\mathrm{CHB}, \mathrm{HBI}$ and $\mathrm{CHC}$ cases $(p=0.072$, $p=0.213$, respectively). Serum albumin, IMA levels and mean and p-values of IMAR of $\mathrm{CHB}, \mathrm{HBI}, \mathrm{CHC}$ cases and the control group are shown in Table 2. 
In $\mathrm{CHB}$ and $\mathrm{CHC}$ cases, serum albumin levels were statistically significantly lower in those with significant fibrosis than those with mild fibrosis ( $p=0.044, p=0.012$, respectively). Again, IMA and IMAR were statistically significantly higher in those with significant fibrosis than those with mild fibrosis $(\mathrm{CHB} ; \mathrm{p}=0.020, \mathrm{p}=0.027$, $\mathrm{CHC}$, respectively; $\mathrm{p}=0.007, \mathrm{p}=0.012$, respectively). Albumin, IMA and IMAR values according to the degree of fibrosis in $\mathrm{CHB}$ and $\mathrm{CHC}$ cases are shown in Table 3.

\section{Discussion}

Hepatitis B and C viruses are two important viruses that cause serious consequences such as LC, fulminant hepatitis and HCC $(8,9)$. Many studies have shown that IMA is the most important isoform of albumin $(6,10)$. It has been reported that IMA concentration does not correlate with age and gender (11). In this study, there was no statistically significant difference between the IMA level and IMAR, and age and gender ( $p>0.05$ ).

In a study, an increased plasma levels of IMA were observed in $\mathrm{CHC}$ cases and it was stated that high IMA concentrations may indicate chronic OS in $\mathrm{CHC}$ infection (12). In another study, it has been shown that IMA is not associated with other parameters more specific for the liver and ALT (4). In this study, there was no significant difference between IMA and IMAR and AST, ALT and AFP ( $p>0.05$ ). Cakir et al. (5) showed that IMA increased in these cases and IMAR was associated with disease severity and liver fibrosis. They stated that as the albumin level decreases in patients with CLD, the IMA level will increase. In another study, it was recommended to use IMAR instead of IMA in patients with advanced liver disease (6).

A change of $1 \mathrm{~g} / \mathrm{dL}$ in albumin causes a $2.6 \%$ change in the IMA level (11). However, the molecular events related to the structural changes that cause the change of serum albumin to IMA have not been fully elucidated (13). In this study, while there was a significant decrease in serum albumin levels in $\mathrm{CHB}, \mathrm{CHC}$ and $\mathrm{HBI}$ compared to the control group, an increase in IMA level was observed $(p=0.001)$. In addition, while there was a significant decrease in serum albumin levels in $\mathrm{CHB}$ and $\mathrm{CHC}$ compared to the $\mathrm{HBI}$ group, an increase in IMA level was found. These findings may be important in terms of demonstrating the importance of ischemia and related OS in liver inflammation due to viral hepatitis.

Another study showed that there is a significant increase in serum IMA levels and IMAR in CLD compared with healthy individuals. In a few cases, IMA has been shown to increase along with other parameters of OS. This suggests that a similar molecular

Table 1. Demographic characteristics of chronic hepatitis $B, H B e A g$ negative chronic infection and chronic hepatitis $C$ cases and the control group, mean values and $p$ values of laboratory tests

\begin{tabular}{|l|l|l|l|l|l|}
\hline & CHB & HBI & CHC & Control & p-value \\
\hline Age & $46.62 \pm 2.69$ & $40.83 \pm 3.71$ & $41.35 \pm 3.58$ & $30.45 \pm 1.08$ & 0.016 \\
\hline Gender (F/M) & $42 / 38$ & $30 / 20$ & $10 / 20$ & $33 / 27$ & 0.063 \\
\hline AST (IU/L) & $39.54 \pm 3.84$ & $24.50 \pm 1.28$ & $46.32 \pm 2.08$ & $24.82 \pm 1.27$ & 0.053 \\
\hline ALT (IU/L) & $68.21 \pm 9.07$ & $26.65 \pm 2.59$ & $42.64 \pm 3.69$ & $26.05 \pm 1.13$ & 0.016 \\
\hline TOT BIL & $0.53 \pm 0.06$ & $0.39 \pm 0.03$ & $0.52 \pm 0.05$ & $0.32 \pm 0.02$ & 0.122 \\
\hline AFP $(\mu / L)$ & $3.25 \pm 0.18$ & $1.98 \pm 0.16$ & $3.40 . \pm 0.33$ & $2.98 \pm 0.21$ & 0.095 \\
\hline PTZ (sn) & $11.58 \pm 0.17$ & $10.97 \pm 0.64$ & $11.70 \pm 0.19$ & $11.30 \pm 0.10$ & 0.107 \\
\hline $\begin{array}{l}\text { F: Female, M: Male, AST: Aspartate amino transferase, ALT: Alanine amino transferase, AFP: Alpha fetoprotein, PTZ: Prothrombin time, TOT BIL: Total bilirubin, CHB: } \\
\text { Chronic hepatitis B, CHC: Chronic hepatitis C, HBI: HBeAg negative chronic infection, HBeAg: Hepatitis B e antigen }\end{array}$ \\
\hline
\end{tabular}

Table 2. Mean and p-values of serum albumin, ischemia modified albumin and ischemia modified albumin/albumin ratios of chronic hepatitis B, HBeAg negative chronic infection and chronic hepatitis $C$ and control group

\begin{tabular}{|l|l|l|l|l|l|}
\hline & CHB & HBI & CHC & Control & p-value \\
\hline Serum albumin (g/dL) & $3.81 \pm 0.04$ & $4.03 \pm 0.03$ & $3.75 \pm 0.03$ & $4.69 \pm 0.04$ & 0.001 \\
\hline Serum IMA (ABSU) & $0.171 \pm 0.01$ & $0.181 \pm 0.01$ & $0.190 \pm 0.01$ & $0.088 \pm 0.01$ \\
\hline IMAR (g/dL) & $0.040 \pm 0.003$ & $0.038 \pm 0.002$ & $0.046 \pm 0.002$ & $0.012 \pm 0.001$ & 0.004 \\
\hline $\begin{array}{l}\text { ABSU: Absorbance units, IMA: Ischemia modified albumin, IMAR: Ischemia modified albumin/albumin ratio, CHB: Chronic hepatitis B, CHC: Chronic hepatitis C, HBI: } \\
\text { HBeAg negative chronic infection, HBeAg: Hepatitis B e antigen }\end{array}$
\end{tabular}

Table 3. Comparison of albumin, ischemia-modified albumin levels, ischemia-modified albumin/albumin ratios according to the degrees of fibrosis in chronic hepatitis B and C cases

\begin{tabular}{|c|c|c|c|c|c|c|}
\hline & \multicolumn{3}{|l|}{ Chronic hepatitis B } & \multicolumn{3}{|l|}{ Chronic hepatitis C } \\
\hline & $\begin{array}{l}\text { Mild fibrosis (stage 1-2) } \\
(n=37)\end{array}$ & $\begin{array}{l}\text { Significant fibrosis } \\
\text { (stage 3-4) }(n=43)\end{array}$ & $\mathrm{p}$-value & $\begin{array}{l}\text { Mild fibrosis } \\
\text { (stage 1-2) }(n=14)\end{array}$ & $\begin{array}{l}\text { Significant fibrosis (stage } \\
3-4)(n=16)\end{array}$ & $\mathrm{p}$-value \\
\hline Albumin & $3.93 \pm 0.09$ & $3.67 \pm 0.06$ & 0.044 & $3.91 \pm 0.082$ & $3.69 \pm 0.035$ & 0.012 \\
\hline IMA & $0.128 \pm 0.019$ & $0.194 \pm 0.015$ & 0.020 & $0.160 \pm 0.003$ & $0.207 \pm 0.005$ & 0.007 \\
\hline IMAR & $0.029 \pm 0.005$ & $0.044 \pm 0.004$ & 0.027 & $0.040 \pm 0.004$ & $0.047 \pm 0.003$ & 0.012 \\
\hline
\end{tabular}


event occurs in chronic hepatitis and that OS and free radicalmediated damage may play an important role in the development of liver failure $(4,14)$. In our study, in line with the results of this study, serum IMA levels and IMAR, in $\mathrm{CHB}, \mathrm{HBI}, \mathrm{CHC}$ were found higher than the control group.

In a study serum IMA and IMAR levels were found to be significantly higher in patients with advanced fibrosis than those with low fibrosis. In addition, it has been stated that IMAR is more valuable than serum IMA concentration in distinguishing cases with mild and advanced fibrosis (6). In this study, serum IMA level and IMAR were significantly higher in those with severe fibrosis than those with mild fibrosis in $\mathrm{CHB}$ and $\mathrm{CHC}$ cases. This may show that IMA and IMAR can affect disease progression and can be used to evaluate fibrosis. This study is the first study in which serum IMA levels and IMAR values were investigated in cases with $\mathrm{HBI}$ according to our literature knowledge.

\section{Study Limitations}

There was no patient group with fibrosis 5 and 6 and HCC. The study had a small sample size, especially cases with $\mathrm{CHC}$. Therefore, large-center studies with larger patient numbers are needed.

\section{Conclusion}

In this study, IMA levels and IMAR were found to be higher in $\mathrm{CHB}, \mathrm{HBI}$ and $\mathrm{CHC}$ patients compared to the control group. In addition, in those with significant fibrosis in $\mathrm{CHB}$ and $\mathrm{CHC}$, IMA level and IMAR were significantly higher than those with mild fibrosis. Early detection of fibrosis is necessary to prevent disease progression and appropriate treatment. IMA, IMAR can be used as a parameters in determining prognosis as an indicator of oxidative liver damage and in the evaluation of fibrosis (especially early detection of fibrosis). Perhaps, treatment methods aimed at preventing the formation of IMA by reducing OS may guide the development of new treatment methods in the future.

\section{Ethics}

Ethics Committee Approval: The study protocol followed the ethical guidelines of the 1975 Helsinki Declaration. Ethics committee approval was obtained from Firat University Institutional Evaluation Committee (approval number: 24, date: 31.05.2018).

Informed Consent: Informed consent form was signed by the patients.

Peer-review: Externally peer-reviewed.

\section{Authorship Contributions}

Concept: S.T., Desing: S.T., Data Collection or Processing: A.Ş., Analysis or Interpretation: A.Ş., Literature Search: A.Ş., Writing: A.Ş., S.T.

Conflict of Interest: No conflict of interest was declared by the authors.
Financial Disclosure: The financial support of the study was provided by the researchers.

\section{References}

1. Bell BP, Manos MM, Zaman A, Terrault N, Thomas A, Navarro VJ, Dhotre KB, Murphy RC, Van Ness GR, Stabach N, Robert ME, Bower WA, Bialek SR, Sofair AN. The epidemiology of newly diagnosed chronic liver disease in gastroenterology practices in the United States: results from population-based surveillance. Am J Gastroenterol. 2008;103:2727-36.

2. Conde SRS, Feitosa RNM, Freitas FB, Hermes RB, Demachki $S$, Araújo MT, Soares MC, Ishak R, Vallinoto AC. Association of cytokine gene polymorphisms and serum concentrations with the outcome of chronic hepatitis B. Cytokin. 2013;61:940-944.

3. Domenicali $M$, Baldassarre $M$, Giannone FA, Naldi $M$, Mastroroberto M, Biselli M, Laggetta M, Patrono D, Bertucci C, Bernardi M, Caraceni P. Post-Transcriptional changes of serum albumin: clinical andprognostic significance in hospitalized patients with cirrhosis. Hepatology. 2014;60:1851-1860.

4. Kumar PA, Subramanian K. The Role of Ischemia Modified Albumin as a Biomarker in Patients with Chronic Liver Disease. J Clin Diagn Res. 2016;10:9-12

5. Cakir M, Karahan SC, Mentese A, Sag E, Cobanoglu U, Polat TB, Erduran E. Ischemia-Modifi ed Albumin Levels in Children with Chronic Liver Disease. Gut and Liver. 2012;6:92-97.

6. Yavuz F, Biyik M, Asil M, Dertli R, Demir A, Polat H, Uysal $S$, Ataseven H. Serum ischemic modified albumin (IMA) concentration and IMA/albumin ratio in patients with hepatitis B-related chronic liver diseases. Turk J Med Sci. 2017;47:947-953.

7. Bar-Or D, Lau E, Winkler JV. A novel assay for cobalt-albumin binding and its potential as a marker for myocardial ischemia-a preliminary report. J Emerg Med. 2000;19:311-315.

8. El-Serag HB. Epidemiology of viral hepatitis and hepatocellular carcinoma. Gastroenterology. 2012;142:1264-73.

9. He D, Li M, Guo S, Zhu P, Huang H, Yan G, Wu Q, Tao S, Tan Z, Wang Y. Expression Pattern of Serum Cytokines in Hepatitis $B$ Virus Infected Patients with Persistently Normal Alanine Aminotransferase Levels. J Clin Immunol. 2013;3:1240-1249.

10. Sahin A, Turkoglu S, Tunc N, Duzenci D, Solmaz OA, Bahcecioglu $\mathrm{IH}$, Yalniz M. Is ischemia-modified albumin a reliable tool for the assessment of acute pancreatitis?. Ther Clinical Risk Manag. 2018;14:627-635

11. Can Ü, Yosunkaya Ş. A New Marker in Ischemia: Ischemia Modified Albumin. Koşuyolu Heart J. 2017;20:148-152.

12. Zuwata-Jagietto J, Warwas M, Pazgan-Simon PM. Ischemiamodified albumin (IMA) is increased in patients with chronic hepatitis $\mathrm{C}$ infection and related to markers of oxidative stress and inflammation. Acta Biochim Pol. 2012;59:661-667.

13. Ahmad P, ul Islam B, Allarakha S, Rabbani G, Dixit K, Moinuddin, Khan $\mathrm{RH}$, Siddiqui SA, Ali A. Preferential recognition of peroxynitritemodified human serum albumin by circulating autoantibodies in cancer. Int J Biol Macromol. 2015;72:875-882

14. Uhing MR. The albumin controversy. Clin Perinatol. 2004;31:475488. 